\title{
ANALISIS FAKTOR KUALITAS PELAYANAN DI KELURAHAN JATIKARYA KECAMATAN JATISAMPURNA KOTA BEKASI
}

Mary Ismowati ${ }^{1}$, Sulatifah $^{2}$

Institut Ilmu Sosial dan Manajemen STIAMI

mary.ismowati@stiami.ac.id ${ }^{1}$,sulatifah1966 @ gmail.com²

\begin{tabular}{l} 
ARSTRACT \\
\hline $\begin{array}{l}\text { AReywords: service quality, } \\
\text { factor analysis }\end{array}$ \\
by the Jatikarya District Office and this is interesting to study to find out \\
more about what factors in service quality are influential and what are the \\
dominant factors in service quality in Jatikarya Village, Jatisampurna \\
District, Bekasi City. This research uses a quantitative approach with factor \\
analysis techniques. A sample of 96 respondents from the Jatikarya urban \\
village community who had and were receiving services in the kelurahan. \\
Questionnaire based on 5 dimensions namely tangibles, responsibility, \\
responsiveness, empathy and assurance with 34 indicators. \\
From the results of the study, it was found that 9 (nine) factors had an \\
effect on the quality of service in Jatikarya Village, Bekasi City. Factors \\
Officer preparedness is the most dominant in influencing the quality of \\
service in Jatikarya Village, Bekasi City with a variance of 33, 590\%. The \\
second factor to the tenth factor is not dominant compared to Factor 1 as \\
having Factor 2 accuracy (8.857\%), factor ability and knowledge of officers \\
(7.863\%), facility completeness factor (6.850\%), service to residents \\
(4.731\%), factor friendliness (4,039\%), information clarity factor (3,833\%), \\
officer neatness factor (3,531\%), and officer patience factor (2,999\%), but in \\
order to achieve organizational goals and better service quality Factor 2 to \\
Factor 9 also should not ignored.
\end{tabular}

\section{LATAR BELAKANG}

Tuntutan masyarakat untuk memperoleh pelayanan yang lebih baik harus disikapi sebagai upaya untuk menciptakan kepuasan dalam pemberian pelayanan kepada masyarakat. Reformasi di bidang pelayanan pubik dilakukan bertujuan untuk meningkatkan efektivitas dan kinerja dari pelayanan publik yang pada akhirnya bertujuan untuk meningkatkan kualitas pelayanan publik kepada masyarakat.

Pelayanan publik yang berkualitas atau pelayanan prima merupakan pelayanan terbaik yang memenuhi standar kualitas pelayanan. Standar Pelayanan adalah tolok ukur yang dipergunakan sebagai pedoman penyelenggaraan pelayanan dan acuan penilaian kualitas pelayanan sebagai kewajiban dan janji penyelenggara pelayanan kepada masyarakat dalam rangka pelayanan yang berkualitas, cepat, mudah, terjangkau, dan terukur (Aldri, 211; Speer, 2012)

Berbagai kebijakan nasional untuk meningkatkan kualitas pelayanan publik adalah upaya nyata dalam mereformasi pelayanan untuk meningkatkan kepuasan masyarakat. Menurut Keputusan Menteri Pendayagunaan Aparatur Negara Nomor 63 tahun 2004 Tentang Pedoman Umum Penyusunan Indeks Kepuasan Masyarakat Unit Pelayanan Instansi Pemerintah, Pelayanan publik adalah segala kegiatan pelayanan yang dilaksanakan oleh penyelenggara pelayanan publik sebagai upaya pemenuhan kebutuhan penerima pelayanan, maupun dalam rangka pelaksanaan ketentuan peraturan perundangundangan. Penyelenggara pelayanan publik adalah petugas pelayanan publik baik Pemerintah Daerah maupun Badan Usaha Milik Daerah. Banyak penelitian mengukur Indeks Kepuasan Masyarakat sudah dilakukan (Wijayanti, 2013, R.Mardiyanto, 2016; Sulistyani, 2016)

Ukuran keberhasilan penyelenggara pelayanan ditentukan oleh tingkat kepuasan pihak penerima pelayanan apabila memperoleh pelayanan sesuai yang dibutuhkan dan diharapkan. Karena itulah perlunya pelayanan bagi masyarakat yang merupakan suatu tujuan pemerintah untuk mensejahterakan masyarakat. 
Demikian juga Kota Bekasi yang terdiri dari 12 Kecamatan melakukan tugas utamanya pelayanan kepada masyarakat sesuai Peraturan Walikota Bekasi Nomor 27 Tahun 2015 Tentang Tata Cara Penyelenggaraan Administrasi Kependudukan Di Kota Bekasi.

Salah satu kecamtan di Kota Bekasi adalah Kecamatan Jatisampurna terdiri dari 5 Kelurahan salah satunya Kelurahan Jatikarya dengan jumlah penduduk 12.095 orang, atau 3.820 Kepala Keluarga. Beragam profesi warga ada buruh petani, pemilik usaha petani, karyawan swasta, karyawan pemerintah, tukang ojek, tukang jahit, tukang kayu dan tukang gali sumur.

Banyak faktor atau dimensi penentu keberhasilan kualitas pelayanan publik di berbagai bidang pelayanan publik seperti bidang kesehatan ( Campos, 1995; Arasli , 2008; Aagja, 2010; Firdaus, 2010; Victor, 2013; ), di bidang transportasi publik ( Tai Lai, 2011; Eboli 2012). Penelitian yang dilakukan banyak merujuk kepada dimensi servqual seperti tangibles, responsiveness, empathy dan ada juga yang meneliti dengan dimensi khusus seperti overall services di rumah sakit, social responsibility dan lain-lain

Berdasarkan survey awal penelitian pada masyarakat Kelurahan Jatikarya dapat dilihat masyarakat masih belum puas diantaranya pengurusan KTP-el, KK, Akte Kelahiran, Surat Nikah Non Muslim dan Surat Keterangan Lainnya, dirasakan masih berbelit-belit, ketidak tepatan waktu pelayanan, sebagian dari aparat pemerintah Kelurahan Jatikarya. Jadi tidak heran lagi sering mendengarkan tuntutan perubahan yang ditujukan kepada aparatur pemerintah, menyangkut pelayanan publik yang diberikan kepada masyarakat. Rendahnya mutu pelayanan publik merupakan citra buruk pemerintah ditengah masyarakat. Dan bagi masyarakat yang pernah berurusan dengan birokrasi selalu mengeluhkan, dan kecewa terhadap tidak layaknya aparatur dalam memberikan pelayanan.

Kelurahan Jatikarya memiliki empat loket pelayanan umum, namun hanya terdapat dua pegawai dari bagian pemerintahan yang bertugas di empat loket pelayanan tersebut sehingga petugas harus membagi tugasnya. Kekurangan petugas ini menyebabkan pengguna layanan harus menunggu dan bahkan pelayanannya dilakukan oleh pegawai yang lain. Perilaku aparat mempunyai peran penting dalam pelayanan public di kecamatan (Tambajong ,2017). Masalah lainnya, mengenai sarana yang masih kurang. Menurunnya jumlah masyarakat yang datang secara langsung di Kantor Kelurahan Jatikarya, minimnya sosialisasi terhadap masyarakat pelayanan publik dalam bentuk pelayanan administrasi. , kurangnya sarana dan prasarana yang memadai.

Kualitas pelayanan yang diberikan Kantor Kecamatan Jatikarya menjadi hal menarik untuk dikaji, karena bermaksud untuk mengetahui lebih mendalam mengenai factor-faktor apa dalam kualitas pelayanan dan faktor apa yang dominan dalam kualitas pelayanan di Kelurahan Jatikarya Kecamatan Jatisampurna Kota Bekasill.

\section{KONSEPTUAL}

\section{Kualitas Pelayanan Publik}

Kualitas pelayanan merupakan salah satu kebijaksanaan penting dalam meningkatkan daya saing produk yang harus memberi kepuasan kepada masyarakat melebihi atau paling tidak sesuai dengan standarisasi kualitas pelayanan.

Kualitas menurut Tjiptono (2007:132) adalah 1). kesesuaian dengan persyaratan/tuntutan, 2). kecocokan pemakaian, 3). perbaikan atau penyempurnaan keberlanjutan, 4). bebas dari kerusakan, 5). pemenuhan kebutuhan pelanggan semenjak awal dan setiap saat, 6). melakukan segala sesuatu secara benar semenjak awal, 7). sesuatu yang bisa membahagiakan pelanggan.

Dalam Manajemen Kinerja sektor Publik kualitas pelayanan dipengaruhi antara lain: (1). kecepatan pelayanan, (2). kebersihan, kerapihan staf, dan fasilitas,(3). keramahan dan kesabaran staf dalam melayani, (4). staf yang membantu dan bersahabat serta perhatian pada pelanggan, dan (5). keamanan dan kenyamanan.

Sinambela, (2014:6) menyebutkan tujuan pelayanan publik pada dasarnya adalah memuaskan masyarakat. Untuk mencapai kepuasan itu dituntut kualitas pelayanan prima yang tercermin dari :

1. Transparansi, Yakni pelayanan yang bersifat terbuka, mudah dan dapat diakses oleh semua pihak yang membutuhkan dan disediakan secara memadai serta mudah dimengerti. 
2. Akuntabilitas, Yakni pelayanan yang dapat dipertanggungjawabkan sesuai dengan ketentuan peraturan per Undang-Undangan

3. Kondisional, Yakni pelayanan yang sesuai dengan kondisi dan kemampuan pemberi dan penerima pelaynan dengan tetap berpegang pada prinsip efisiensi danefektivitas.

4. Partisipatif, Yaitu pelayanan yang dapat mendorong peran serta masyarakat dalam penyelenggaraan pelayanan publik dengan memperhatikan aspirasi, kebutuhan, dan harapan masyarakat.

5. Kesamaan hak, Yaitu pelayanan yang tidak melakukan diskrimanasi dilihat dari aspek apapun khususnya suku, ras, agama, golongan, status sosial, dll.

6. Keseimbangan hak dan kewajiban, Yaitu pelayanan yang mempertimbangkan aspek keadilan antara pemberidan penerima pelayanan publik.

Dengan demikian, untuk dapat menilai sejauh mana mutu pelayanan publik yang diberikan aparatur pemerintah, memang tidak bisa dihindari, bahwa menjadi tolak ukur kualitas pelayanan dapat ditelaah dari kriteria dimensi-dimensi kualitas pelayanan publik.

Parasuraman, Zeitthaml dan Berry (1985: 43) mengidentifikasi sepuluh faktor utama yang menentukan kualitas pelayanan yang diringkas menjadi 5 (lima) dimensi pokok SERVQUAL (kualitas pelayanan),sebagai berikut:

1) Bukti langsung (tangibles), meliputi fasilitas fisik, perlengkapan, pegawai dan sarana komunikasi.

2) Keandalan (reliability), yakni kemampuan memberikan paelayanan yang dijanjikan segera, akurat dan memuaskan.

3) Daya tanggap (responsiveness), yaitu kemampuan para staf untuk membantu para pelanggan dan memberikan pelayanan dengan tanggap.

4) Jaminan (assurance) mencakup pengetahuan, kemampuan, kesopanan dan sifat dapat dipercaya yang dimiliki para staf, bebas dari bahaya, resiko ataupun keragu-raguan.

5) Empati (emphathy) mencakup kemudahan dalam melakukan hubungan komunikasi yang baik, perhatian pribadi dan memahami kebutuhan para pelanggan

Menurut Ratminto dan Atik Septi Winarsih (2015:4-6) pengertian pelayanan publik atau pelayanan umum adalah : -Pelayanan Publik atau pelayanan umum dapat didefinisikan sebagai segala bentuk jasa pelayanan, baik dalam bentuk barang publik maupun jasa publik yang pada prinsipnya menjadi tanggung jawab dan dilaksanakan oleh instansi pemerintah di pusat, di daerah, dan di lingkungan Badan Usaha Milik Negara atau Badan Usaha Milik Daerah, dalam upaya pemenuhan kebutuhan masyarakat maupun dalam rangka pelaksanaan ketentuan peraturan perundang-undangan.

Pelayanan publik atau pelayanan umum dan pelayanan administrasi pemerintahan atau perijinan tersebut mungkin dilakukan sebagai upaya pemenuhan kebutuhan masyarkat.

Upaya memberikan layanan yang terbaik ini dapat diwujudkan apabila kita dapat menonjolkan kemampuan, sikap, penampilan, perhatian, tindakan dan tanggung jawab yang baik dan terkoordinasi.

Pelayanan publik diartikan, pemberian layanan (melayani) keperluan orangatau masyarakat yang mempunyai kepentingan pada organisasi itu sesuai dengan aturan pokok dan tata cara yang telah ditetapkan. Selanjutnya menurut KEPMENPAN No.63/KEP/M.PAN/7/2003, publik adalah segala kegiatan pelayanan yang dilaksanakan oleh penyelenggara pelayanan publik sebagai upaya pemenuhan kebutuhan penerima pelayanan maupun pelaksanaan ketentuan peraturan perundangundangan.

Berdasarkan ciri dan sifat kegiatan dalam proses pelayanan serta produk pelayanan yang dihaslkan, dapat dibedakan menjadi :

a. Jenis pelayanan administratif, yaitu Jenis pelayanan yang diberikan oleh unit pelaynan berupa kegiatan pencatatn, penelitian, pengambilan keputusan, dokumentasi dan kegiatan tata usaha lainnya yang secara keseluruhan menghasilkan produk akhir berupa dokumen, misalnya, sertifikat, izin-izin, pelayanan Administrasi kependudukan (KTP, Akta Kelahiran dan Akta Kematian).

b. Jenis pelayanan barang, yaitu jenis pelayanan yang diberikan oleh unit pelayanan berupa kegiatan penyediaan, dan atau pengolahan bahan berwujud fisik termasuk distribusidan 
penyampiannya kepada konsumen langsung (sebagai unit atau sebagai individual) dalam satu system. Contohnya : pelayanan listrik, pelayanan air, telepon

c. Jenis pelayanan jasa, yaitu jenis pelayanan yang diberikan oleh unit pelayanan berupa penyediaan sarana dan prasarana serta penunjangnya.

\section{Prinsip-Prinsip Pelayanan Publik}

Standar Pelayanan Publik menurut Keputusan Menteri PAN nomor 63/KEP/M.PAN/7/2003, sekurang kurangnya melipti :

1) Prosedur Pelayanan : Prosedur pelayanan yang dibakukan bagi pemberi dan penerima pelayanan termasuk pengaduan.

2) Waktu penyelesaian :Waktu penyelesaian yang ditetapkan sejak saat pengajuan permohonan sampai dengan penyelesaian pelayanan termasuk pengaduan.

3) Biaya pelayanan :Biaya/tarif pelayanan termasuk rinciannya yang ditetapkan dalam proses pemberian pelayanan.

4) Produk pelayanan :Hasil pelayanan yang akan diterima sesuai dengan ketentuan yang telah ditetapkan.

5) Sarana dan Prasarana :Penyediaan sarana dan prasarana pelayanan yang memadai oleh penyelenggara pelayanan publik.

6) Kompetensi petugas pelayanan : Kompetensi petugas pemberi pelayanan harus ditetapkan dengan tepat berdasarkan pengetahuan, keahlian, ketrampilan, sikap, dan perilaku yang dibutuhkan (dalam Ratminto dan Winarsih, 2007:23)

Tentang pentingnya kompetensi petugas dalam pelayanan sejalan dengan pendapat R.Mardiyanto, (2016:196) — diperlukan adanya pembenahan dalam sistem dan petugas pelayanan dan harus selalu memperhatikan apa saja yang sedang dibutuhkan masyarakatl . Supendi ( 2016: 5953 ) juga mengatakan hal yang sama - pelayanan aparatur bersifat terbuka, mudah diakses oleh semua pihak dilaksanakan dengan penuh tanggung jawab, mengakomodasikondisi khusus yang dihadapi masyarakat tanpa mengabaikan prinsip efisinesi dan efektifitas pelayananll.

\section{Kepuasan Masyarakat}

Kepuasan sebagai tingkat perasaan seseorang setelah membandingkan hasil yang dirasakan dengan harapannya. Dengan demikian dapat dikatakan bahwa kepuasan merupakan respon sikap individu yang bersifat subyektif terhadap obyek tertentu setelah membandingkannya antara harapan dan kenyataan. Kepuasan masyarakat merupakan faktor utama yang harus diperhatikan oleh penyedia pelayanan publik, karena kepuasan masyarakat akan menentukan keberhasilan pemerintah dalam menyelenggarakan pelayanan publik. Definisi kepuasan masyarakat sering disama artikan dengan definisi kepuasan pelanggan atau kepuasan konsumen, hal ini hanya dibedakan pada siapa penyedia dan apa motif diberikannya pelayanan tersebut.

Kepuasan pelanggan juga sangat dipengaruhi oleh tingkat pelayanan. Faktor pendukung kepuasan di antaranya faktor kesadaran para pejabat atau petugas yang bertugas dalam pelayanan umum, faktor aturan yang menjadi landasan kerja pelayanan, faktor organisasi yang merupakan alat serta sistem yang memungkinkan berjalannya mekanisme kegiatan pelayanan, faktor pendapatan yang dapat memenuhi kebutuhan hidup minimum, faktor keterampilan petugas, dan faktor sarana dalam pelaksanaan tugas pelayanan (Dewi, Rahmatunnisa, Sumaryana, \& Kristiadi, 2018).

\section{Kerangka Berfikir}

Berkaitan dengan masalah pelayanan publik, Kelurahan Jatikarya Kecamatan Jatisampurna pada hakekatnya dituntut untuk memberikan pelayanan yang berkualitas dengan tujuan akhir tercapainya kepuasan seluruh masyarakat di Kota Bekasi. Kepuasan masyarakat dapat diperoleh apabila terdapat kesesuaian antara nilai kinerja pelayanan dengan nilai kinerja harapan masyarakat terhadap pelayanan itu sendiri. Kualitas pelayanan diartikan sebagai penilaian pelanggan terhadap tingkat instansi tersebut. Dengan kata lain tindakan pelanggan akan sangat ditentukan oleh penilaian yang dilakukan dan diberikan oleh instansi.

Untuk itu dilakukan penelitian supaya mengetahui factor-faktor dalam Kualitas Pelayanan pelayanan publik di Kantor Kelurahan Jatikarya kecamatan Jatisampurna Kota Bekasi. 


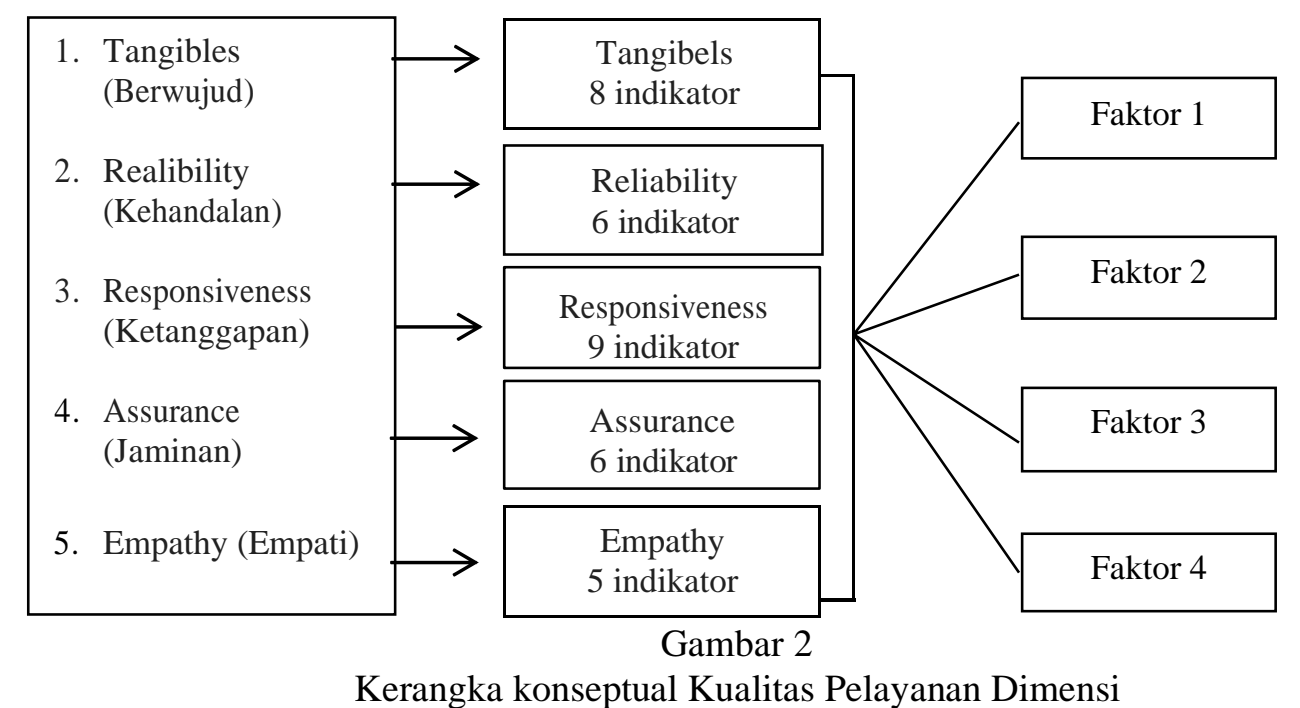

\section{Hipotesis penelitian}

Hipotesa merupakan suatu anggapan sementara yang perlu diuji kebenarannya. Untuk mengetahui pengaruh antara variable bebas dengan variable terikat, maka dalam penulisan tesis ini hipotesis yang penulis ajukan adalah :

1. Faktor-faktor Kualitas Pelayanan berpengaruh di Kantor Kelurahan Jatikarya Kecamatan Jatisampurna.

2. Ada Faktor Dominan pada Kualitas Pelayanan di Kantor Kelurahan Jatikarya Kecamatan Jatisampurna.

\section{METODE PENELITIAN}

Desain penelitian yang digunakan dalam penelitian ini adalah pendekatan kuantitatif yakni suatu metode dalam meneliti status sekelompok manusia, suatu objek, suatu kondisi, suatu situasi kondisi dengan tujuan membuat gambaran deskripsi atau lukisan secara sistematis, faktual dan akurat mengenai fakta-fakta, sifat-sifat serta hubungan antar fenomena yang diselidiki

Secara metodologis guna memperoleh data yang representatif, Survey pengukuran Indeks Kepuasan Masyarakat ini menggunakan metode yang memungkinkan terkonfirmasinya persepsi masyarakat secara utuh tentang pelayanan yang mereka dapatkan di lingkungan Kelurahan Jatikarya Kecamatan Jatisampurna Kota Bekasi. Oleh karenanya, melalui metode survey dengan pendekatan kuantitatif sangat tepat digunakan untuk mencapai tujuan tersebut.

Definisi operasional yang digunakan dalam penelitian ini dari pelayanan publik dikenal sebagai metode SERVQUAL yang dikembangkan oleh Zeithaml dkk, 1985. adalah Tangible ( 8 indikator), Reliability (6 indikator), Responsiveness (9 indikator), Assurance (6 indikator), dan Empathy (5 indikator) total ada 34 indikator atau factor yang akan diteliti.

Data primer yang digunakan dalam penelitian ini didapatkan dengan cara menyebarkan angket kepada responden masyarakat yang ada di wilayah Kelurahan Jatikarya Kecamatan Jatisampurna Kota Bekasi, serta pernah mendapatkan layanan dari pemerintahan desa di desanya masing-masing. Penyebaran kuesioner diacak (random).

Populasi dalam penelitian ini adalah masyarakat yang sedang atau pernah mendapatkan pelayanan dari pemerintahan kelurahan Jatikarya sebanyak 10.156 orang yang tersebar di 14 (empat belas) RW. Teknik pengambilan sampel yang digunakan adalah simple random sampling (pemilihan sampel secara acak,) dihitung dengan menggunakan rumus proportional random sampling dengan alpha 5\% didapatkan jumlah sampel 96 orang. 


\section{Teknik Analisis Data}

\section{Analisis Deskriptif}

Analisis statistik deskriptif adalah statistik yang digunakan untuk menganalisis data dengan cara mendeskripsikan data yang telah terkumpul tanpa membuat kesimpulan yang berlaku untuk umum atau generalisasi. Termasuk dalam statistic deskriptif antara lain perhitungan mean, median, dan modus, perhitungan penyebaran data melalui perhitungan rata-rata dan standar deviasi serta penyajian data melalui tabel frekuensi dan grafik histogram.

\section{Analisis Faktor}

Prinsip utama dalam analisis faktor adalah korelasi, artinya variabel yang memiliki korelasi erat akan membentuk suatu faktor, sedangkan variabel yang ada dalam suatu faktor akan memiliki korelasi yang lemah dengan variabel yang terdapat pada faktor yang lain. Karena prinsip utama analisis faktor adalah korelasi, maka asumsi dalam analisis faktor berkatian dengan korelasi sebagai berikut:

a. Korelasi atau keterkaitan antar variabel harus kuat.

b. Indeks perbandingan jarak antar koefisien korelasi dengan koefisien korelasi parsialnya secara keseluruhan harus kecil.

Hal ini dapat diidentifikasikan dengan nilai Kaiser Meyer Olki Measure of Sampling Adequancy (KMO). KMO merupakan sebuah indeks perbandingan jarak antara koefisien korelasi dengan koefisien korelasi parsialnya secara keseluruhan. Jika jumlah kuadrat koefisien korelasi parsialnya diantara seluruh pasangan variabel bernilai kecil dibandingkan dengan jumlah kuadrat koefisien korelasi, maka akan menghasilkan nilai KMO yang mendekati satu. Nilai KMO yang kecil menunjukkan bahwa analisis faktor bukan merupakan pilihan yang tepat. Untuk dilakukan analisis faktor, nilai KMO dianggap cukup apabila nilai $\mathrm{KMO} \geq 0,5$.

c. Indeks perbandingan jarak antara koefisien korelasi dengan koefisien korelasi parsialnya secara keseluruhan harus kecil.

Hal ini dapat diidentifikasikan dengan nilai Measure of Sampling Adequancy (MSA). MSA merupakan sebuah indeks perbandingan jarak antara koefisien korelasi dengan koefisien parsialnya secara parsial setiap item/variabel. Untuk dapat dilakukan analisis faktor, nila MSA dianggap cukp apabila nilai MSA $\geq 0,5$. Apabila terdapat item/variabel yang tidak memiliki nilai MSA $\geq 0,5$ variabel tersebut harus dikeluarkan dari analisis faktor secara bertahap satu persatu.

Model analisis faktor yang digunakan pada penelitian ini adalah principal components analysis dengan rumus sebagai berikut:

$\mathrm{F} \mathrm{m}=\mathrm{Am} 1 \mathrm{X} 1+\mathrm{Am} 2 \mathrm{X} 2+\ldots \ldots .+\mathrm{Am}$ PFP

Dengan syarat $\mathrm{m} \leq \mathrm{p}$. Jika ditulis dalam bentuk matriks adalah: $\mathrm{F}=\mathrm{A} X$

Dimana:

$\mathrm{Xi} \quad=$ Variabel yang diteliti.

$\mathrm{A}=$ Bobot dari kombinasi linear (loading)

$\mathrm{F}=$ Faktor principat components

$\mathrm{m} \quad=$ Jumlah faktor umum

\section{Uji Ketepatan Model Analisis Faktor}

Digunakan untuk melihat apakah faktor-faktor yang terbentuk berdasarkan analisis faktor benarbenar valid. Ada dua cara untuk menguji ketepatan model dari faktor-faktor yang telah terbentuk. Secara garis besar analisis faktor dapat dilakukan dengan beberapa tahap, yaitu sebagai berikut:

\section{Merumuskan Masalah}

\section{Membuat Matriks Korelasi}

Proses analisis faktor didasarkan pada matriks korelasi antara variabel yang satu dengan yang lain, untuk memperoleh analisis yang semua variabelnya harus korelasi. Untuk mengujinya dilakukan dengan uji Barletts Test Sphericity dan Kaiser - Mayer - Olkin (KMO) untuk mengetahui kecukupan sampelnya. Uji ini dapat dilihat pada tabel berikut: 
Tabel 1. Ukuran Ketepatan Kaiser-Mayer-Olkin

\begin{tabular}{|ll|}
\hline Ukuran KMO & Rekomendasi \\
\hline 0,9 & Baik sekali \\
\hline 0,8 & Baik \\
\hline 0,7 & Sedang \\
\hline 0,6 & Cukup \\
\hline 0,5 & Kurang \\
\hline$<0,5$ & Ditolak \\
\hline
\end{tabular}

Sumber : Subhas Sharma (1994)

\section{Penentuan Jumlah Faktor}

Diperlukan untuk mewakili variabel-variabel yang akan dianalisis didasarkan pada besarnya eigenvalue serta persentase total variannya. Hanya faktor yang memiliki eigenvalue $\geq 1$ yang dipertahankan dalam model analisis faktor, sedangkan yang lainnya dikeluarkan dari model.

\section{Rotasi Faktor}

Hasil dari ekstraksi faktor dalam matriks faktor mengidentifikasikan hubungan antar faktor dan variabel individual, namun masih banyak faktor yang berkorelasi sehingga sulit diinterpretasikan. Melalui rotasi faktor matriks, faktor matriks ditransformasikan kedalam matriks yang lebih sederhana sehingga mudah diinterpretasikan. Rotasi faktor menggunkan varimax.

\section{Interpretasi Faktor}

Dilakukan dengan mengklasifikasikan variabel yang mempunyai factor loading minimum 0,4 variabel, factor loading kurang dari 0,4 dikeluarkan dari model.

\section{Penamaan faktor yang ada.}

Setelah faktor benar - benar sudah terbentuk, maka proses dilanjutkan dengan menamakan faktor yang ada.

\section{Lokasi dan Jadwal Penelitian}

Lokasi penelitian ini di Kelurahan Jatikarya Kecamatan Jatisampurna Kota Bekasi, dengan pengambilan data yang tersebar di 1 Kelurahan,14 RW dan 60 RT. Penelitian ini direncanakan selama 4 bulan dari September-Desember 2018.

\section{HASIL PENELITIAN}

\section{Analisis Deskriptif}

Dari gambaran umum penilaian responden terhadap kualitas pelayanan terlihat dari distribusi data yang terdapat pada lampiran, terlebih dahulu dikelompokkan ke dalam interval kelas. Pengelompokkan ini diambil menurut nilai terendah sampai nilai tertinggi. Dengan demikian diperoleh rentang empiris antara 68 sampai 117 dengan rentang 49. Kemudian dari hasil analisis data diperoleh skor rata-rata (mean) sebesar 104,85, median 103, modus 103, standar deviasi 9,18 dan varians 84,2.

Berdasarkan jumlah responden 96 dan skala likert 1-5 sehingga didapatkan perhitungan sebagai berikut:

a. Batas atas rentang skor : $\left(\% \mathrm{~F}^{*} 5\right) / 5=(96 * 5) / 5=96$

b. Batas bawah rentang skor : $\left(\% \mathrm{~F}^{*} 1\right) / 5=\left(96^{*} 1\right) / 5=19,2$

Berdasarkan diatas, angka indeks yang dihasilkan menunjukkan skor 19,2 - 96 dengan rentang sebesar 76,8. Dengan menggunakan three box method, maka rentang 76,8/3 $=25,6$ dibagi menjadi tiga bagian dengan kriteria lemah, sedang dan kuat, sehingga menghasilkan rentang interpretasi indeks sebagai berikut:

Penilaian skor:

1. Lemah $=19,2-44,8$

2. Sedang $=44,8-70,4$ 
3. Kuat $=70,4-96$

Dari penilian skor diatas maka deskripsi hasil jawaban responden terhadap kualitas pelayanan berdasarkan 5 dimensi adalah sebagai berikut:

a. Tangibles

Tanggapan responden tentang indikator dari tangible ditunjukkan. Berdasarkan hasil deskriptif tanggapan responden tentang tangibles menunjukkan nilai rata-rata 62 terletak pada rentang kategori sedang.

b. Reliability

Tanggapan responden tentang indikator dari reliability. Berdasarkan hasil deskriptif tanggapan responden tentang reliability menunjukkan nilai rata-rata 60 terletak pada rentang kategori sedang.

c. Responsiveness

Tanggapan responden tentang indikator dari responsiveness. Berdasarkan hasil deskriptif tanggapan responden tentang responsiveness menunjukkan nilai rata-rata 56 terletak pada rentang kategori sedang.

d. Assurance: Berdasarkan hasil deskriptif tanggapan responden tentang assurance menunjukkan nilai rata-rata 59 terletak pada rentang kategori sedang.

e. Empathy

Berdasarkan hasil deskriptif tanggapan responden tentang empathy menunjukkan nilai ratarata 58 terletak pada rentang kategori sedang.

\section{Matrik Korelasi}

Uji analisis fakor menggunakan prinsip korelasi. Artinya, jika sebuah indikator valid mangukur sebuah variabel, 34 indikator tersebut harus berkorelasi secara signifikan dan kuat dengan indikator lain di sesama variabel. Analisis faktor menguji korelasi antar sesama indikator baik secara simultan maupun parsial. Berikut ini merupakan uji statistik yang digunakan untuk melihat korelasi antar 34 indikator.

Tabel 2. Hasil Uji KMO \& Bartlett's Test KMO and Bartlett's Test

\begin{tabular}{|c|c|c|}
\hline \multicolumn{2}{|c|}{$\begin{array}{l}\text { Kaiser-Meyer-Olkin Measure of Sampling } \\
\text { Adequacy. }\end{array}$} & .777 \\
\hline & Approx. Chi-Square & 2416.513 \\
\hline Bartlett's Test of & df & 561 \\
\hline Spmericity & Sig. & .000 \\
\hline
\end{tabular}

Sumber : Penelitian 2018

Berdasarkan ouput diatas diperoleh bahwa nilai Sig Bartlett 0,000 lebih kecil dari 0,5 sehingga H0 ditolak. Artinya terdapat korelasi antar 34 indikator pada variabel yang mengukur kualitas pelayanan. Pada hasil tersebut juga diperoleh bahwa nilai KMO adalah sebesar 0,777. Berdasarkan hasil tersebut dapat disimpulkan bahwa terdapatnya korelasi antar 34 indikator pada variabel laten telah terpenuhi.

\section{Measure of Sampling Aduequacy (MSA)}

Berbeda dengan Kaiser Mayer Olkin (KMO), kuatnya korelasi antar indikator secara parsial dinilai dari nilai Measure of Sampling Aduequacy (MSA). Asumsi akan terpenuhi jika nilai MSA > $50 \%$ atau 0,5 .seperti pada lampiran .

Korelasi antar 34 indikator dinyatakan kuat apabila nilai anti-image correlation yang memiliki nilai diatas 0,5. Dengan demikian, indikator tersebut valid untuk mengukur kualitas pelayanan.

Berdasarkan hasil diatas, diperoleh bahwa nilai Anti-image Correlation untuk semua indikator lebih besar dari 0,5 maka 34 indikator tersebut valid untuk mengukur variabel yang dapat mengukur kualitas pelayanan sehingga dapat digunakan untuk pengujian selanjutnya. 


\section{Menentukan Jumlah Faktor}

Untuk menentukan berapa faktor yang dapat diterima secara empirik dapat dilakukan berdasarkan besarnya eigenvalue setiap faktor yang muncul. Semakin besar eigenvalue setiap faktor, semakin representatif faktor tersebut untuk mewakili sekelompok variabel. Faktor-faktor ini yang dipilih adalah faktor yang mempunyai eigenvalue sama dengan atau lebih dari satu.

Tabel Total Variance Explained berguna untuk menentukan berapakah faktor yang mungkin dapat dibentuk. Pada lampiran 1 table Total Variance Explained, 34 indikator yang dianlisis dapat dikelompokkan menjadi 9 faktor, yaitu eigenvalues yang menunjukkan angka lebih besar dari satu. Dengan demikian terdapat 9 faktor yang terbentuk.

\section{Rotasi Faktor}

Sekalipun dari ke-34 variabel telah terbentuk faktor-faktor, namun perlu dilakukan rotasi untuk memperjelas variabel-variabel mana yang masuk ke dalam tiap-tiap faktor. Rotated Component matrix merupakan nilai loading faktor dari tiap-tiap variabel. Loading faktor merupakan besarnya korelasi antara faktor yang terbentuk dengan variabel tersebut di lampiran 2.

\section{Component Transformation Matrix}

Tabel Component Transformation Matrix menunjukkan hasil rotasi varimax dimana variabelvariabel sudah terdistribusikan ke masing-masing faktor yaitu 9 faktor yang terbentuk pada Lampiran 3 Component Transformation Matrix. Tabel menunjukkan bahwa pada component 1 nilai korelasi $0,575>0,5$, component 2: $0,539>0,5$, component $3: 0,505>0,5$, component 4: $0,517>0,5$, component 5: 0,760>0,5, component 6: 0,681 >0,5, component 7: 0,539>0,5, component 8: 0,702 > 0,5 dan component 9: 0,664 >0,5. Karena semua component >0,5 maka kesembilan faktor yang terbentuk dapat dikatakan tepat dalam merangkum 34 variabel yang ada.

\section{Menentukan label faktor}

Setelah faktor-faktor terbentuk, ternyata variabel-variabel yang masuk pada masing-masing faktor tidak sama dengan yang diprediksi sebelumnya. Oleh karenanya, perlu memberikan nama label baru yang representative bagi variabel-variabel yang masuk didalam masing-masing faktor-faktor sebagai berikut: Kesiapan petugas $(33,590 \%)$, Ketepatan $(8,857 \%)$, Kemampuan dan pengetahuan petugas $(7,863 \%)$, Kelengkapan fasilitas $(6,850 \%)$, Pelayanan kepada warga $(4,731 \%)$, Keramahan petugas $(4,039 \%)$, Kejelasan informasi $(3,833 \%)$, Kerapian petugas $(3,531 \%)$, dan Kesabaran petugas $(2,999 \%)$. Jumlah varians tersebut diatas kurang dari $100 \%$, menunjukkan masih tedapat faktor-faktor lain yang belum terungkap, yaitu: ekonomi, teknologi, politik dan budaya.

\section{PEMBAHASAN}

Berdasarkan hasil analisis dari data tentang penilaian responden terhadap faktor-faktor yang mempengaruhi kualitas pelayanan di Kelurahan Jatikarya, Kecamatan Jatisampurna Kota bekasi, dapat diperoleh sembilan faktor yang berpengaruh terhadap kualitas pelayanan di Kelurahan Jatikarya, Kota Bekasi, faktor-faktor tersebut dapat dijelaskan pada tabel dibawah ini.

Tabel 3. Nama Faktor Baru yang Terbentuk

\begin{tabular}{|c|l|l|c|}
\hline \multirow{2}{*}{$\begin{array}{c}\text { No. } \\
\text { Faktor } \\
\text { Baru }\end{array}$} & \multicolumn{1}{|c|}{ Indikator } & \multirow{1}{|c|}{$\begin{array}{c}\text { Nama } \\
\text { Indikator } \\
\text { Baru }\end{array}$} \\
\cline { 2 - 3 } & \multicolumn{1}{|c|}{ No } & \multicolumn{1}{|c|}{ Nama } & $\begin{array}{c}\text { Kesiapan } \\
\text { petugas }\end{array}$ \\
\cline { 2 - 3 } & Keandalan 4 & Pengawasan petugas/pegawai pelayanan & \\
\cline { 2 - 3 } & Kharisma & $\begin{array}{l}\text { Petugas/pegawai pelayanan selalu siap } \\
\text { membantu }\end{array}$ & \\
\cline { 2 - 3 } & Tepat 1 & $\begin{array}{l}\text { Memberikan pelayanan sesuai kebutuhan } \\
\text { warga }\end{array}$ & \\
\cline { 2 - 3 } & Tepat 2 & $\begin{array}{l}\text { Ketepatan pelayanan sesuai jadwal yang } \\
\text { ditentukan }\end{array}$ & \\
\cline { 2 - 3 } & Arsip & $\begin{array}{l}\text { Kotak saran dan masukan untuk warga } \\
\text { petugas/pegawai }\end{array}$ & \\
\cline { 2 - 3 } & Informasi 1 &
\end{tabular}




\begin{tabular}{|c|c|c|c|}
\hline & Informasi 2 & Kejelasan jenis pelayanan admninistrasi & \\
\hline \multirow[t]{6}{*}{2} & Pelayanan & $\begin{array}{l}\text { Setiap petugas/pegawai sudah menggunakan } \\
\text { komputer }\end{array}$ & \multirow[t]{6}{*}{ Ketepatan } \\
\hline & Jasa 1 & Call center darurat 24 jam & \\
\hline & Jasa 2 & Kunjungan Lurah kepada warga & \\
\hline & Keandalan 1 & Kehadiran petugas/pegawai pelayanan & \\
\hline & Keandalan 2 & Waktu buka meja/counter pelayanan & \\
\hline & Keandalan 3 & Waktu tutup meja/counter pelayanan & \\
\hline \multirow[t]{4}{*}{3} & Respon 2 & $\begin{array}{l}\text { Respon petugas/pegawai terhadap warga } \\
\text { yang ingin mendapatkan pelayanan } \\
\text { administrasi di kelurahan }\end{array}$ & \multirow{4}{*}{$\begin{array}{l}\text { Kemampuan } \\
\text { dan } \\
\text { pengetahuan } \\
\text { petugas }\end{array}$} \\
\hline & Kepercayaan 1 & $\begin{array}{l}\text { Memberikan arahan dengan baik kepada } \\
\text { warga untuk mendapatkan pelayanan } \\
\text { kependudukan }\end{array}$ & \\
\hline & Kepercayaan 2 & $\begin{array}{l}\text { Penguasaan materi dan kemampuan } \\
\text { petugas/pegawai memberikan penjelasan } \\
\text { kepada warga }\end{array}$ & \\
\hline & Aman & $\begin{array}{l}\text { Memiliki petugas/pegawai pelayanan yang } \\
\text { menjamin }\end{array}$ & \\
\hline \multirow[t]{5}{*}{4} & Lokasi & Kebersihan ruangan terjaga & \multirow{5}{*}{$\begin{array}{c}\text { Kelengkapan } \\
\text { Fasilitas }\end{array}$} \\
\hline & Fasilitas 1 & $\begin{array}{l}\text { Tersedia alat-alat kebersihan kantor } \\
\text { kelurahan }\end{array}$ & \\
\hline & Fasilitas 2 & Tersedia kendaraan angkut sampah & \\
\hline & Fasilitas 3 & Ketersediaan ruang tunggu yang nyaman & \\
\hline & Penampilan 1 & Tampilan gedung menarik dan parkir luas & \\
\hline \multirow[t]{3}{*}{5} & Perhatian 2 & $\begin{array}{l}\text { Memahami kebutuhan warga terhadap } \\
\text { ketersediaan sarana dan prasarana umum di } \\
\text { lingkungan kelurahan }\end{array}$ & \multirow[t]{3}{*}{$\begin{array}{c}\text { Pelayanan } \\
\text { kepada warga }\end{array}$} \\
\hline & Paham & $\begin{array}{l}\text { Memberikan bantuan dan merespon kejadian } \\
\text { luar biasa kepada warga di kelurahan yang } \\
\text { berhubungan dengan terjadinya wabah } \\
\text { penyakit dan musibah kebakaran }\end{array}$ & \\
\hline & Waktu & $\begin{array}{l}\text { Upaya memberikan pelayanan sesuai waktu } \\
\text { yang ditentukan }\end{array}$ & \\
\hline \multirow[t]{3}{*}{6} & Ramah & $\begin{array}{l}\text { Keramahan petugas/pegawai dalam } \\
\text { memberikan pelayanan }\end{array}$ & \multirow[t]{3}{*}{$\begin{array}{c}\text { Keramahan } \\
\text { Petugas }\end{array}$} \\
\hline & Sopan & $\begin{array}{l}\text { Memiliki petugas/pegawai pelayanan yang } \\
\text { sopan }\end{array}$ & \\
\hline & Perhatian 1 & $\begin{array}{l}\text { Aparatur terkait ikut serta terlibat dalam } \\
\text { setiap kegiatan sosial, kegiatan keagamaan } \\
\text { dan berbagai event yang diselenggarakan } \\
\text { oleh warga }\end{array}$ & \\
\hline \multirow[t]{3}{*}{7} & Informasi 3 & Informasi kegiatan sosial kelurahan & \multirow{3}{*}{$\begin{array}{l}\text { Kejelasan } \\
\text { Informasi }\end{array}$} \\
\hline & Cepat & $\begin{array}{l}\text { Kecepatan petugas/pegawai dalam melayani } \\
\text { warga }\end{array}$ & \\
\hline & Layanan 1 & $\begin{array}{l}\text { Tanggapan petugas/pegawai terhadap } \\
\text { keluhan warga }\end{array}$ & \\
\hline \multirow[t]{2}{*}{8} & Layanan 2 & $\begin{array}{l}\text { Menerima komplain atas pelayanan yang } \\
\text { diterima oleh warga }\end{array}$ & \multirow[t]{2}{*}{ Responsif } \\
\hline & Penampilan 2 & Penampilan petugas/pegawai selalu rapi & \\
\hline 9 & Respon 1 & $\begin{array}{l}\text { Kesabaran petugas/pegawai dalam } \\
\text { menerima keluhan dan pengaduan warga }\end{array}$ & $\begin{array}{l}\text { Kesabaran } \\
\text { Petugas }\end{array}$ \\
\hline
\end{tabular}

Sumber : Penelitian 2018

Faktor kesiapan petugas (Pengawasan petugas/pegawai pelayanan, Petugas/pegawai pelayanan selalu siap membantu, Memberikan pelayanan sesuai kebutuhan warga, Ketepatan pelayanan sesuai jadwal yang ditentukan, Kotak saran dan masukan untuk warga, Kepastian jadwal pelayanan petugas/pegawai, dan Kejelasan jenis pelayanan admninistrasi) merupakan faktor yang paling dominan dalam mempengaruhi kualitas pelayanan di Kelurahan Jatikarya, Kota Bekasi dengan 
varians sebesar 33,590\%. Sedangkan Faktor kedua hingga faktor kesepuluh memang tidak dominan dibandingkan Faktor 1, namun demi tercapainya tujuan organisasi dan kualitas pelayanan yang semakin baik Faktor 2 sampai dengan Faktor 10 juga tidak boleh diabaikan.

\section{KESIMPULAN}

Berdasarkan hasil penelitian dan pembahasan mengenai faktor-faktor yang mempengaruhi kualitas pelayanan di Kelurahan Jatikarya Kecamatan Jatisampurna Kota Bekasi dari penelitian ini adalah sebagai berikut:

1. Berdasarkan analisis dari data tentang penilaian respondent terhadap faktor-faktor yang mempengaruhi kualitas pelayanan di Kelurahan Jatikarya, Kecamatan Jatisampurna Kota Bekasi, dapat diperoleh sembilan faktor yang berpengaruh terhadap kualitas pelayanan di Kelurahan Jatikarya, Kota Bekasi.

2. Faktor Kesiapan petugas adalah yang paling dominan dalam mempengaruhi kualitas pelayanan di Kelurahan Jatikarya, Kota Bekasi dengan varians sebesar 33, $590 \%$. Sedangkan faktor kedua hingga faktor kesepuluh memang tidak dominan dibandingkan Faktor 1, namun demi tercapainya tujuan organisasi dan kualitas pelayanan yang semakin baik Faktor 2 sampai dengan Faktor 10 juga tidak boleh diabaikan

\section{Saran}

a. Disarankan untuk terus memperhatikan dan meningkatkan kesiapan petugas diantaranya Pengawasan petugas/pegawai pelayanan, Petugas/pegawai pelayanan selalu siap membantu, Ketepatan pelayanan sesuai jadwal yang ditentukan, Kepastian jadwal pelayanan petugas/pegawai dan Kejelasan jenis pelayanan admninistrasi karena menurut masyarakat hal inilah yang dibutuhkan dari pelayanan Kelurahan Jatikarya Kecamatan Jatisampurna Kota Bekasi.

b. Faktor lain tidak boleh diabaikan untuk ditingkatkan diantaranya Ketepatan, Kemampuan dan pengetahuan petugas, Kelengkapan fasilitas, Pelayanan kepada warga, Keramahan petugas, Kejelasan informasi, Kerapian petugas, dan Kesabaran petugas.

c. Memberikan kemudahan kepada masyarakat dalam menyampaikan masukannya adalah hal yang perlu untuk dilakukan. Namun akan lebih baik apabila semua usaha perbaikan kualitas pelayanan ini agar dilakukan berkelanjutan.

\section{DAFTAR PUSTAKA}

Aagja , Jayesh P., Renuka Garg , 2010, Measuring perceived service quality for public hospitals (PubHosQual) in the Indian context, International Journal of Pharmaceutical and Healthcare Marketing, ISSN: 1750-6123, 6 April 2010

Aldri Frinaldi , 2011, PENGARUH BUDAYA KERJA ETNIK TERHADAP BUDAYA KERJA KEBERANIAN DAN KEARIFAN PNS DALAM PELAYANAN PUBLIK YANG PRIMA (STUDI PADA PEMERINTAH KABUPATEN PASAMAN BARAT), Proceeding Simposium Nasional Otonomi Daerah 2011 ISBN: 978-602-96848-2-7 LAB-ANE FISIP Untirta

Arasli , Huseyin, Erdogan Haktan Ekiz, Salih Turan Katircioglu,2008, Gearing service quality into public and private hospitals in small islands, International Journal of Health Care Quality Assurance, Vol 2 (1) pp : 8-23

Aries Djaenuri Enceng. 2017, Sistem Pemerintah Daerah. Universitas Terbuka, Tangerang Selatan.

Ratminto dan Atik Septi Winarsih, 2015, Manajemen Pelayanan, Pustaka Pelajar, Yogyakarta.

Campos, Doug -Outcalt, etc, 1998, Decentralization of health services in Western Highlands Province, Papua New Guinea: An attempt to administer health service at the subdistrict level, Social Sciences and Medicine, Vol 40 (8), 1995 PP : 1091-1098 
Dewi, M. P., Rahmatunnisa, M., Sumaryana, A., \& Kristiadi, J. B. (2018). Ensuring Service Quality in Education for Indonesia's Sustainable Education. Journal of Social Studies Education Research Sosyal, 9(4), 65-81. https://doi.org/10.17499/jsser.26856

Eboli , Laura and Gabriella Mazzulla, 2007, Service Qualitu Atributes Affecting Customer Satisfaction For Bus Transit, Journal of Public Transportation, Vol 10 ( 3) Pages : 21-34

Firdaus Zuhdi dan Abi Muhlisin, 2010, ANALISIS FAKTOR YANG BERHUBUNGAN DENGAN KEPUASAN PASIEN RAWAT INAP DI RUMAH SAKIT ISLAM SURAKARTA, Jurnal Kesehatan UMS, Vol 3 ( 1) 2010

Pitri Yandri,2013, Kepuasan Masyarakat Terhadap Pelayanan Kelurahan Setelah Pemekaran Di Tangerang Selatan ,Jurnal Liquidity, Vol 2 (2) 2013

Pasolong, 2007, Administrasi Publik, Alfabeta, Bandung, 2008.

R.Mardiyanto dan Mary Ismowati, 2017, Analisis Indeks Kepuasan Masyarakat dalam Upaya Peningkatan Kepuasan Kualitas Pelayanan Masyarakat di Kantor Kecamatan Kotabaru Kabupaten Karawang, transparansi, vol 9 (2) september 2017 , http://ojs.stiami.ac.id/index.php/transparansi/article/view/23/22

Sinambela, 2014, Reformasi Pelayanan Public, Cetakan Ke Tujuh, Bumi Aksara,Jakarta, 2010.

Speer,Johanna, Participatory Governance Reform: A Good Strategy for Increasing Government Responsiveness and Improving Public Services? World Development, Vol 40 (12) PP : 2379 2398

Smith, Peter C. and Andrew Street,2005 Measuring the efficiency of public services: the limits of analysis Statistic in Society, Vol 168 (2) , 263-462, https://doi.org/10.1111/j.1467985X.2005.00355.x

Supendi, 2016, Analisis Tingkat Kepuasan Pelayanan KonsumenMelalui Kualitas Datadan Perilaku Anti Korupsi Pada Badan Pusat Statistik DKI Jakarta Tahun 2015, Jurnal Ilmu dan Budaya, Vol 40 ( 52) Juli 2016

Tai Lai,Wen and Ching-FuChen, 2011, Behavioral intentions of public transit passengers-The roles of service quality, perceived value, satisfaction and involvement, Transport Policy, Vol 18 (2) 2011, Pages 318-325

Tambajong, Hesty dan Zulfan Nahrudin, 2017, The Behavior of Apparatus and Cultural Organization in Provision of Public Service in District Level, Journal of Arts, Humanities and Social Sciences, ISSN 2347-5374

Tjiptono, 2004. Prinsip-Prinsip Total Quality Service, Bayu Media Publishing,Yogyakarta.

Tjiptono, 2005. Pemasaran Jasa, Edisi Pertama, Bayu Media Publishing, Malang.

Victor Lorin Purcărea, 2013, The Assessment of Perceived Service Quality of Public Health Care Services in Romania Using the SERVQUAL Scale, procedia economics and Finance, Vol 6, Pages : 573-585

Zeithaml, Valeria A., A.Parasuraman, and L.L.Berry. (1985). A Conceptual model of service quality and its implications for future researchll, Journal of marketing, P.44. 